\title{
KOMUNIKASI TERAPEUTIK KONSELOR LAKTASI TERHADAP KLIEN RELAKTASI
}

\author{
Retasari Dewi \\ BRI Kantor Cabang BSD
}

\begin{abstract}
ABSTRAK
Tujuan dari penelitian ini adalah untuk memahami bagaimana proses komunikasi terapeutik antara konselor dengan klien, bagaimana teknik komunikasi terapeutik digunakan dalam konseling dan untuk mengetahui mengapa komunikasi terapeutik diperlukan dalam proses relaktasi. Metode yang digunakan dalam penelitian ini adalah metode kualitatif dengan pendekatan studi kasus. Teori interaksi simbolik dan teori self-disclosure menjadi perspektif dalam menganalisis fenomena kasus komunikasi antara konselor dengan kliennya.

Hasil dari penelitian ini menunjukkan bahwa konseling relaktasi pada intinya adalah kegiatan komunikasi antarpribadi yang bertujuan untuk terapi kesehatan. Selama konseling relaktasi terjadi proses komunikasi antara konselor dengan klien. Konselor menggunakan teknik komunikasi untuk membantu klien mengatasi kendala klien dalam menyusui. Disimpulkan bahwa proses komunikasi terapeutik konselor laktasi terdiri dari tiga tahapan yaitu tahap pembinaan hubungan baik, tahap pengumpulan informasi dan tahap penyelesaian masalah. Ada sepuluh teknik komunikasi yang digunakan konselor dalam konseling relaktasi yaitu: Komunikasi nonverbal, mendengarkan, mengajukan pertanyaan, menggunakan respons sederhana, berempati, menghindari kata-kata menghakimi/menilai, menerima apa yang klien pikirkan, mengenali dan memuji, memberikan informasi yang relevan, dan terakhir memberikan saran. Komunikasi terapeutik diperlukan dalam proses konseling relaktasi, dan kompetensi komunikasi adalah kompetensi utama yang harus dimiliki konselor laktasi.
\end{abstract}

Kata-kata kunci: Komunikasi terapeutik, konselor, relaktasi, studi kasus, interaksi simbolik

\section{THERAPEUTIC COMMUNICATION OF LACTATION COUNSELORS WITH RELACTATION CLIENTS}

\begin{abstract}
The purpose of this research is to understand how the process of therapeutic communication between counselor and client, how therapeutic communication techniques used in counseling, and why therapeutic communication needed in relactation process. The method used in this study is qualitative method with a case study approach. Symbolic interaction theory and the theory of self-disclosure is used as a perspective to analyze the phenomenon of communication case of counselor and their clients. The results of this study indicate that the relactation counseling is the core of interpersonal communication activities in health therapy area. Communication process happens between counselor and his client during the counseling of relactation activities. Counselors use communication techniques to help clients resolve problems in breastfeeding. It is concluded that therapeutic communication process in relactation counseling consists of three stages, the first stage is good relationship exercise, the second stage is information gathering and the last stage is problem solving. There are ten communication techniques used by counselor in relactation counseling namely: nonverbal communication, listening, asking questions, use simple responsse, empathy, avoiding judgmental words, accept what clients think, recognizing and praising clients, providing relevant information, and the last one is giving advice. Therapeutic communication is required in the relactation counseling process, as communication competence is the core competencies that should be possessed by lactation counselors.
\end{abstract}

Keywords: Therapeutic communication, counselors, relactation, case studies, symbolic interaction

Koresponsdensi: Retasari Dewi, M.I.Kom. BRI Kantor Cabang BSD, Jl. Kapten Soebianto Djojokusumo Kav.BSD II No.1 Serpong-Tangerang.Email: neng_reta@yahoo.com 


\section{PENDAHULUAN}

Semakin banyaknya fasilitas kesehatan dan tenaga kesehatan membuat masyarakat punya lebih banyak pilihan. Fasilitas kesehatan saling berlomba menghadirkan teknologi-teknologi terbaru di bidang kesehatan, demikian juga tenaga kesehatan terus berusaha meningkatkan pelayanan yang profesional ahli di bidangnya, dan lebih komunikatif. Karena sudah tidak zaman lagi tenaga kesehatan yang kaku dan tidak komunikatif.

Salah satu profesi baru di bidang kesehatan yang mungkin masih terdengar asing di telinga adalah konselor laktasi. Konselor laktasi adalah seseorang yang membantu ibu yang mengalami kesukaran pada saat menyusui. Rista Pikatan adalah satu dari banyak ibu yang mengalami kesulitan dalam menyusui, karena ia terkena baby blues syndrome setelah melahirkan putri pertamanya. Karena air susunya tidak keluar, ibu Rista memberikan susu formula pada bayinya. Namun ternyata bayinya menunjukkan gejala alergi yang cukup berat terhadap susu formula. Ia sudah mendatangi beberapa dokter, tetapi tidak mendapat jawaban yang memuaskan karena dokter yang tidak komunikatif dan larangan detailing di rumah sakit. Di tengah kebingungannya ibu Rista mendapat informasi dari internet mengenai konselor laktasi Asosiasi ibu Menyusui Indonesia (AIMI) yang bisa memberikan bantuan konseling kepada ibu yang mengalami kasus seperti yang dialami Rista.

Konselor laktasi saat ini telah menjadi profesi baru di bidang kesehatan yang berperan penting dalam meningkatkan jumlah ibu menyusui di Indonesia. Seorang konselor tidak hanya membantu ibu menghilangkan kesulitannya dalam menyusui, tetapi konselor juga adalah seorang profesional, pendidik, coach, motivator, cheerleding, sahabat, bahkan mungkin bisa dikatakan sebagai tokoh inspirasional.

Konselor laktasi berasal dari berbagai kalangan. Tenaga kesehatan seperti dokter umum, dokter spesialis anak, bidan, perawat, banyak yang tergerak menjadi konselor laktasi. Di samping tenaga kesehatan, banyak juga konselor yang berasal dari masyarakat umum, yang tidak memilliki background pendidikan ilmu kesehatan yaitu ibu rumah tangga, pegawai negeri sipil, guru, pengusaha, dan masih banyak lagi. Beberapa dari mereka tergerak untuk menjadi konselor laktasi karena ingin membantu orang lain yang mengalami kesulitan menyusui. Sebelum menjadi konselor laktasi yang bersertifikat, mereka harus mengikuti pelatihan dengan modul dari World Health Organization (WHO) dan United Nation of Children's Fund (UNICEF) selama empat puluh jam.

Berdasarkan data yang dilansir Departemen Kesehatan dalam Riset Kesehatan Dasar (Riskesdas) 2010 mengenai Presentase Kategori Menyusui Eksklusif dengan kriteria dalam 24 jam terakhir bayi hanya disusui/diberi ASI saja, pada bayi di bawah usia dua bulan sebanyak $74 \%$ dari total bayi yang menyusui secara eksklusif. Presentase tersebut menurun seiring dengan bertambahnya usia bayi yakni $66,9 \%$ pada bayi usia 3 bulan dan $54 \%$ pada bayi usia 5 bulan. Itu berarti ada sekitar $26 \%$ bayi di bawah usia dua bulan telah diberikan susu formula dan satu dari tiga bayi di usia 2-3 bulan telah diberikan makanan tambahan.

Rendahnya angkaibu menyusui di Indonesia ini karena berbagai faktor. Ada faktor medis dan faktor nonmedis yang menjadi penyebab ibu tidak dapat menyusui anaknya. Faktor medis seperti terkena HIV, tuberculosis aktif, dan perempuan yang mendapat pengobatan tertentu, karena disekresikan ke dalam Air Susu Ibu (ASI) sehingga membahayakan bayi. Faktor lain yang menjadi alasan mengapa para ibu memilih berhenti memberikan ASI berkaitan dengan banyak hal, diantaranya rasa sakit saat menyusui, volume ASI rendah, kembali bekerja, pemberian makanan tambahan, khawatir bentuk payudara rusak, ASI tidak keluar/keluar sedikit atau karena alasan lain.

Menurut dr. Utami Roesli, Sp.A., dari 100 ibu yang mengalami kesulitan menyusui hanya 2 ibu yang benar-benar kesulitan karena kelainan anatomi payudara, dan 1 orang yang bayinya mengalami kelainan anatomi mulut. Sisanya sebanyak 97 orang ibu sebenarnya hanya kurang informasi dan kurang percaya diri. Hal ini karena, "Menyusu bagi bayi adalah insting tapi bagi ibu, menyusui adalah learning."

Para ibu yang sempat berhenti menyusui tapi ingin kembali menyusui, sebenarnya ada caranya karena ternyata produksi ASI dari seorang ibu dapat diaktifkan kembali. Jika ibu tersebut memutuskan kembali menyusui anaknya setelah berhenti menyusui sama sekali beberapa lama, ini disebut dengan relaktasi atau kembali menyusui. Menurut Nia Umar, ketua 
Ikatan Konselor Menyusui Indonesia (IKMI), kunci utama keberhasilan relaktasi adalah "confident dan commitment". Tugas konselor laktasi adalah membantu ibu meningkatkan kepercayaan dirinya dan menguatkan komitmennya untuk terus menyusui anaknya karena ditengah kesibukan ibu, kemudahan mendapatkan susu formula ditambah lagi dengan iklan yang provokatif, memberikan ASI adalah bentuk perjuangan. Perjuangan yang dilakukan dengan keringat, air mata dan darah ibu.

Konselor laktasi tidak seperti tenaga kesehatan lainnya. Tenaga kesehatan lain memiliki dasar pendidikan ilmu yang lebih dalam mengenai kesehatan, tetapi kekurangan mereka yaitu tidak memiliki keterampilan komunikasi terapeutik yang baik. Tenaga kesehatan dilatih untuk menemukan masalah dan memperbaikinya, sedangkan dengan keterampilan komunikasi, konselor membantu seseorang untuk memutuskan sendiri yang terbaik baginya.

Stress yang dialami ibu dapat menyebabkan terganggunya hormon prolaktin, yaitu hormon yang bertugas memproduksi ASI. Untuk itu, bantuan dari konselor laktasi yang lebih komunikatif dari pada kebanyakan tenaga kesehatan sangat dibutuhkan. Dengan membangun hubungan terapeutik dengan kliennya, konselor berusaha memahami secara menyeluruh apa yang menjadi kendala bagi klien, dan berdialog dengan klien untuk membantu klien menemukan solusi agar klien dapat menyusui anaknya lagi.

Pendekatan konselor laktasi pada klien lebih kepada pendekatan pribadi dengan menjalin keakraban dan tidak ada jarak antara keduanya. Hubungan yang terjadi antara konselor dan klien lebih mengarah pada hubungan pertemanan dan hubungan kekeluargaan, maksudnya adalah hubungan tanpa jarak. Konselor tidak memosisikan diri lebih tahu dari klien. Terjadinya hubungan pertemanan dan hubungan kekeluargaan menunjukkan telah terjadinya hubungan terapeutik antara konselor laktasi dan klien selama konseling berlangsung. Hubungan terapeutik ini ditandai dengan adanya sebuah ikatan antara konselor dan klien, klien mau terbuka dan menceritakan kesulitannya selama menyusui, klien mempercayai konselor, klien mau melaksanakan saran dari konselor, klien berhasil menyusui dan adanya kedekatan hubungan antara klien dan konselor.

Membangun hubungan merupakan hal terpenting dalam pekerjaan keperawatan, terutama dalam terapi atau penyembuhan. Dalam komunikasi terapeutik, konselor dan klien terlibat dalam suatu proses interaksi. Melalui proses interaksi, terjadi hubungan timbal balik yang ditandai dengan tukar menukar informasi, perilaku, perasaan, pikiran dan pengalaman.

Keterampilan komunikasi yang dimiliki konselor akan berpengaruh pada kualitas hubungan antara konselor dan klien dan akan berdampak pula pada pencapaian tujuan konseling. Konselor harus dapat menjalin hubungan baik agar memperoleh kepercayaan dari klien dan meminimalisasi jurang pemisah yang mungkin terjadi antara konselor dengan klien.

Peneliti melihat realitas bahwa di dalam kehidupan sehari-hari manusia tidak terlepas dari hubungan dengan manusia lain (interaksi) yang pada akhirnya hubungan itu akan menjadi proses komunikasi seperti halnya hubungan terapeutik yang ingin dibangun konselor laktasi bersama klien. Dalam penelitian ini peneliti mencoba mengetahui tahapan-tahapan yang terjadi dalam komunikasi terapeutik yang di dalamnya melibatkan interaksi dan pemakaian simbol komunikasi oleh konselor laktasi kepada klien relaktasi. Penelitian ini juga mencoba menjelaskan teknik komunikasi terapeutik yang digunakan saat konseling laktasi dan mengapa komunikasi diperlukan dalam proses relaktasi.

\section{METODE PENELITIAN}

Metode yang digunakan dalam penelitian ini tidak dimaksudkan untuk memberikan arahan yang dapat menjelaskan fenomena kasus komunikasi terapeutik yang terjadi pada konseling laktasi, akan tetapi hanya dijadikan sebagai perspektifdalammenganalisis fenomena komunikasi konselor laktasi. Adapun perspektif teori yang dipergunakan dalam penelitian ini adalah Teori Interaksi Simbolik dari George Harbert Mead dan Teori Self Disclosure.

Dalam komunikasi terapeutik yang terjadi antara konselor dan klien, terjadi pertukaran symbol secara dinamis yang akan dimaknai oleh satu sama lain. Dengan komunikasi yang intens diharapkan konselor dapat mengungkap makna dan latar belakang kesulitan klien dalam menyusui, sedangkan klien mendapat informasi 
baru mengenai laktasi dan dukungan untuk dapat terus menyusui.

Esensi interaksionisme simbolik adalah suatu aktivitas yang merupakan ciri khas manusia, yakni komunikasi atau pertukaran simbol yang diberi makna. Berdasarkan kerangka berfikir dari Interaksi Simbolik, perspektif ini berupaya memahami perilaku manusia dari sudut pandang subjek. Sehingga kilen yang mengalami kesulitan menyusui harus dilihat sebagai proses yang memungkinkan klien tersebut membentuk dan mengatur perilaku mereka mempertimbangkan ekspektasi orang lain yang menjadi mitra interaksi mereka dalam hal ini konselor dan keluarga. Karena manusia bertindak hanya berdasarkan definisi atau penafsiran mereka atas objek-objek disekeliling mereka.

Dalam pandangan perspektif ini, sebagaimana ditegaskan Blumer, proses sosial dalam kehidupan kelompoklah yang menciptakan dan menegakkan aturan-aturan, bukan aturan-aturan yang menciptakan dan menegakkan kehidupan kelompok. Menurut teoritisi perspektif ini, kehidupan sosial adalah "interaksi manusia dengan menggunakan simbol-simbol". Karena itu penulis memandang, perilaku manusia adalah hasil dari interpretasi mereka pada dunia disekeliling mereka.

Proses komunikasi dan interaksi antara klien dan konselor dilakukan dengan menggunakan simbol-simbol yang dipahami maknanya melalui proses belajar. Tindakan klien dan konselor dalam proses interaksi itu bukanlah suatu tanggapan langsung terhadap stimulus yang datang, melainkan dari hasil sebuah proses interpretasi terhadap stimulus. Jadi, jika pada akhirnya terjadi kesamaan makna mengenai pentingnya menyusui, hal ini merupakan hasil proses belajar, dalam arti memahami simbolsimbol dan saling menyesuaikan makna dari simbol-simbol tersebut. Meskipun perbedaan norma, nilai sosial dan makna dari simbolsimbol itu memberikan pembatasan terhadap tindakan klien dan konselor, namun dengan kemampuan berpikir yang dimilikinya, klien dan konselor bebas menentukan tindakan dan tujuan-tujuan yang hendak dicapainya.

Penggunaan terori self disclosure dalam penelitian ini melukiskan bahwa dalam pengembangan hubungan konselor dan klien terdapat empat kemungkinan sebagaimana terwakili melalui keempat jendela tersebut.
Tugas seorang konselor sangatlah penting dalam menggali dan mengungkap permasalahan klien dengan memperbesar open area klien. Dengan teknik komunikasi terapeutik konselor mampu menciptakan kondisi agar klien bersikap terbuka dan memperkecil hidden area, dan klien mau menerima informasi baru mengenai menyusui sehingga mempersempit blind area klien.

Landasanteoretisdalampenulisanpenelitian ini akan dibahas beberapa konsep yang disusun menjadi landasan konseptual. Konsep-konsep yang akan dibahas yaitu mengenai: komunikasi kesehatan dan komunikasi terapeutik.

Liliwerimengatakan, komunikasi kesehatan adalah studi yang mempelajari bagaimana cara menggunakan strategi komunikasi untuk menyebarluaskan informasi kesehatan yang dapat memengaruhi individu dan komunitas agar mereka dapat membuat keputusan yang tepat berkaitan dengan pengelolaan kesehatan (Liliweri, 2007: 46).

Landasan konseptual yang digunakan sebagai acuan dalam penelitian ini adalah komunikasi terapeutik yang dapat digunakan sebagai alat terapi dalam konseling kesehatan medis atau kekonseloran. Keliat (1996: 34) menjelaskan bahwa "Komunikasi terapeutik pada hakekatnya merupakan bentuk dari komunikasi interpersonal yang secara khusus ditujukan untuk proses pemulihan atau terapi tertentu. Sehingga dalam prakteknya komunikasi terapeutik digunakan dalam lingkup yang terbatas."

Hubungan terapeutik antara konselor laktasi dan klien adalah hubungan komunikasi antarpribadi yang bertujuan untuk membantu klien yang mengalami kesulitan menyusui terutama dari sisi kejiwaan. Hubungan ini berlangsung dalam dialog dua arah yang ditandai dengan tukar menukar perilaku, perasaan, pikiran, dan pengalaman menyusui. Hubungan terapeutik ini dilakukan dengan sengaja menggunakan keterampilan interaksi konselor untuk memberikan semangat dan mendukung perubahan-perubahan positif dalam diri klien.

Sikap komunikasi antarpribadi berpotensi lebih besar dalam proses perubahan sikap dibandingkan komunikasi yang lain. Karena itu kecenderungan teknik yang digunakan dalam komunikasi terapeutik adalah komunikasi antarpribadi. Perbedaan antara komunikasi antarpribadi dengan komunikasi terapeutik 
adalah tujuannnya. Komunikasi ini terjadi antara tenega kesehatan seperti dokter, perawat, terapis dengan pasien atau klien yang memiliki masalah kesehatan.

Metode penelitian yang digunakan dalam penelitian ini adalah metode kualitatif. Secara teoritik, metode kualitatif adalah suatu jenis penelitian kontekstual yang menjadikan manusia sebagai instrumen utama (human instrument) serta disesuaikan dengan situasi yang dihadapi (natural setting). Penelitian menggunakan metode kualitatif ini merupakan sebuah penelitian yang memiliki tujuan utama yaitu untuk mengkaji makna-makna dari sebuah perilaku, simbol maupun fenomena-fenomena yang terjadi. Metode kualitatif menitikberatkan suatu pandangan tentang sebuah fakta sosial yang berdasar pada penilaian dan juga penjabaran yang bersifat subjektif.

Pendekatan yang dipakai dalam penelitian "Komunikasi Terapeutik Konselor Laktasi dengan Klien Relaktasi" ini adalah studi kasus. Tujuan dari penelitian ini adalah menyelidiki dan mempelajari kasus relaktasi secara intensif dan menyeluruh. Peneliti menganggap bahwa studi kasus adalah pendekatan yang tepat untuk meneliti kasus komunikasi terapeutik yang terjadi pada proses relaktasi, karena untuk memperoleh gambaran mendalam mengenai kasus ini diperlukan berbagai macam informasi dari berbagai sumber.

Subjek penelitian yang sering juga disebut informan dalam penelitian ini adalah seseorang yang dapat memberikan informasi lebih banyak tentang kasus yang sedang diteliti, dibandingkan dengan orang lain. Jumlah informan yang diambil tidak menjadi masalah yang besar karena yang menjadi fokus dalam penelitian ini adalah kelengkapan dan keakuratan data yang dapat diberikan oleh informan sehubungan dengan penelitian yang dilakukan. Subjek penelitian ini dipilih dengan cara purposif berdasarkan kriteria yang diperlukan.

Dalam penelitian ini terdapat lima unsur yang menjadi key informant yaitu: (1) Fasillitator dalam pelatihan konselor laktasi, sebanyak dua orang, (2) Konselor Laktasi, dua orang, (3) Konsultan komunikasi kesehatan, satu orang, (4) Klien yang menjalankan program relaktasi, dua orang, dan (5) Keluarga klien, dua orang. Sedangkan objek penelitian ini adalah komunikasi terapeutik yang terjadi selama klien relaktasi berlangsung yaitu kata- kata dan tindakan (perilaku) yang dilakukan oleh konselor selama proses konseling.

\section{HASIL DAN PEMBAHASAN}

Komunikasi adalah transaksi. Maksud dari komunikasi adalah transaksi bahwa komunikasi merupakan suatu proses, komponenkomponennya saling terkait dan para komunikatornya beraksi dan bereaksi sebagai suatu kesatuan atau keseluruhan. (Barnlund, 1970 dikutip dari DeVito 1997:47). Komunikasi merupakan suatu proses, suatu kegiatan. Meski terkadang komunikasi dibicarakan seakanakan ini merupakan proses statis, yang diam, komunikasi tidak pernah seperti itu. Segala hal dalam komunikasi selalu berubah komunikator, komunikan dan lingkungan mereka.

Dalam setiap proses transaksi, komponenkomponen komunikasi saling terkait secara integral dengan setiap elemennya. Elemenelemen komunikasi saling bergantung, tidak pernah independen. Contohnya tidak aka nada pesan tanpa sumber dan tidak ada umpan balik tanpa adanya penerima. Karena sifatnya yang saling tergantung ini, perubahan pada salah satu komponen mengakibatkan perubahan pada komponen yang lain.

Budi Anna Keliat (1996: 34) dalam bukunya yang berjudul Komunikasi Terapeutik Konselor dan Klien menjelaskan bahwa:

"Komunikasi terapeutik pada
hakekatnya merupakan bentuk dari
komunikasi interpersonal yang
secara khusus ditujukan untuk proses
pemulihan atau terapi tertentu.
Sehingga dalam prakteknya komunikasi
terapeutik digunakan dalam lingkup
yang terbatas."

Komunikasi terapeutik berdasarkan kutipan di atas menunjukkan bahwa hakekatnya komunikasi terapeutik menjadi bagian dari proses terapi yang sedang dijalankan sehingga diharapkan mampu mempercepat proses pemulihan dari klien terutama dari sisi psikologi/ kejiwaan. Dalam situasi seperti ini hubungan terapeutik berlangsung dalam bentuk dialog dan percakapan. Komunikasi terapeutik pada prinsipnya merupakan komunikasi profesional yang mengarah pada tujuan. Komunikasi ditujukan untuk membina kerjasama konselor dan klien, ditandai dengan tukar menukar 


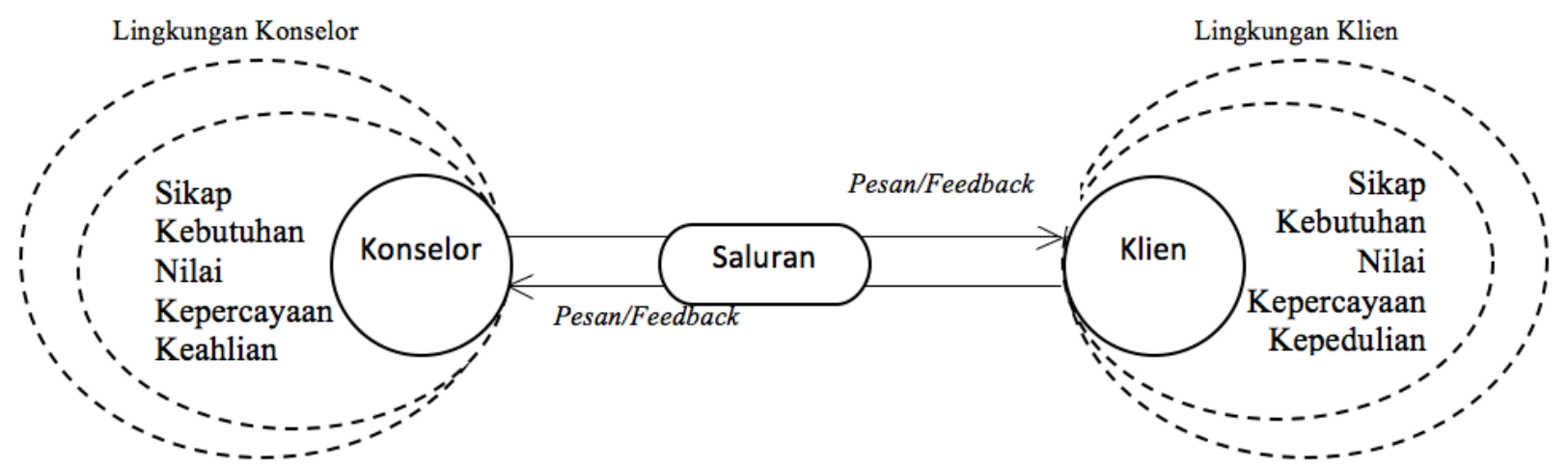

Gambar 1 Model Komunikasi Terapeutik Konselor Laktasi dan Klien Relaktasi, berdasarkan hasil penelitian

perilaku, perasaan, pikiran, dan pengalaman dalam membina hubungan yang terapeutik.

Hubungan yang terapeutik adalah hubungan yang mana seorang anggota dengan sengaja menggunakan keterampilan interaksi untuk memberikan semangat dan mendukung perubahan-perubahan diri anggota lainnya. Dengan konseling laktasi ini diharapkan agar klien memperoleh pemahaman yang lebih baik mengenai dirinya dan pandangannya mengenai menyusui. Mengarahkan klien kearah perkembangan yang lebih optimal, mampu memecahkan masalah yang dihadapinya dan mempunyai wawasan yang objektif mengenai menyusui. Keberhasilan klien untuk menyusui memungkinkan klien merasa lebih bahagia dalam hidupnya dan terhindar dari kecemasan dan perasaan ketakutan karena tidak memberikan yang terbaik untuk anaknya. Hubungan konselor dan klien yang terapeutik tidak mungkin dapat dicapai tanpa komunikasi.

Komunikator dalam komunikasi terapeutik diasumsikan sebagai konselor dan komunikan adalah klien. Komunikasi yang terjadi antara keduanya berlangsung secara langsung atau tatap muka. Baik konselor maupun klien peneliti gambarkan sebagai dua orang yang setara dalam berkomunikasi, karena pesan suatu pihak sekaligus juga adalah umpan balik bagi pihak lain. Antara konselor dan klien terdapat garis yang menunjukan interaksi antara kedua pihak. Konselor dan klien saling mengirim pesan dan mengirim feedback pada saat yang bersamaan. Pesan dan feedback yang disampaikan melewati sebuah saluran, karena komunikasi terapeutik adalah komunikasi secara tatap muka maka saluran yang digunakan untuk menyampaikan pesan adalah lima panca indra yaitu indra penglihatan, pendengaran, perabaan, penciuman, dan perasa. Dari yang dipaparkan Esthetika Wulandari, komunikator dan komunikan dipengaruhi oleh faktor-faktor seperti: sikap, kebutuhan, nilai, keyakinan, keahlian konselor, sedangkan pada klien faktor seperti kepedulian klien pada issue menyusui berpengaruh pada penerimaan pesan. Faktorfaktor yang disebutkan tadi dipengaruhi juga oleh lingkungan sekitar konselor dan klien, bagaimana pengalaman dan lingkungan memaknai issue menyusui. Inilah sebabnya penelitian ini menggunakan teori interaksi simbolik karena setiap bentuk interaksi sosial yang dilakukan oleh setiap individu, akan mempertimbangkan sisi individu tersebut.

Faktor-faktor yang mempengaruhi klien, penelitigambarkan dalam lingkaran dengan garis yang putus-putus. Maksudnya adalah faktorfaktor tersebut bisa berubah atau justru semakin kuat karena pengaruh dari lingkungan ataupun pengaruh interaksi dengan orang lain. Kondisi ini memungkinkan terjadinya perubahan atau pembentukan perilaku baik pada klien maupun konselor karena terjadi pembentukan makna menyusui yang berasal dari pikiran mengenai dirinya dan hubungannya interaksi antara keduanya yang bertujuan untuk memediasi dan menginterpretasi makna menyusui yang menjadi kerangka rujukan mereka masing-masing. Sikap yang dimaksud pada model komunikasi terapeutik di atas adalah sikap pada kegiatan menyusui, sikap ini adalah kecenderungan bertindak, berpersepsi, berfikir dan merasa dalam menghadapi kegiatan menyusui. Bila sikap klien positif terhadap kegiatan menyusui maka ia akan setuju pada ide-ide atau informasi mengenai menyusui dan saran konselor untuk terus menyusui. Sikap berasal dari pengalaman, tidak dibawa dari lahir, tetapi merupakan hasil 
belajar. Ini sejalan dengan apa yang disampaikan Mead dalam teori interaksi simbolik. Konsep individu biologis dimaknai Mead sebagai individu yang polos dan belum mendapatkan pengaruh apa-apa dari lingkungannya. Dan ketika individu itu mulai memasuki wilayah mikro seperti keluarga atau makro yaitu masyarakat pada umumnya, maka individu itu akan terpengaruh dalam perilakunya. Kerangka rujukan yang tidak cermat akan menghambat efektifitas pemecahan masalah karena sikap orang tersebut akan cenderung defensive dan merasionalisasikan kekeliruan. Karena itu dibutuhkan pendekatan atau interaksi yang baik antara konselor dengan klien, karena perilaku manusia merupakan hasil interaksi antara keunikan individual dengan keumuman situasional.

Faktor yang kedua adalah kebutuhan, kebutuhan mencakup kebutuhan biologis dan kebutuhan psikologis. Faktor kebutuhan memiliki peranan yang sangat menentukan dalam pembentukan perilaku. Abraham Maslow dalam Rakhmat (2005:37), mengatakan ada empat motif sosiogenis yaitu kebutuhan akan rasa aman (safety needs), kebutuhan akan keterikatan dan cinta (belongingness and true love), kebutuhan akan penghargaan (esteem needs) dan kebutuhan untuk pemenuhan diri (self-actualization). Untuk merubah perilaku klien, konselor harus mengetahui apa yang menjadi kebutuhan klien. Jika alasan klien ingin menyusui kembali adalah karena alasan medis seperti bayi alergi susu formula, maka konselor bisa memanfaatkan isu itu untuk terus mendorong klien konsisten dalam mencoba menyusui kembali.

Dalam menghadapi kehidupan, manusia membutuhkan nilai-nilai untuk menuntunnya dalam mengambil keputusan atau memberikan makna pada kehidupannya. Bila manusia kehilangan nilai, maka ia tidak akan tahu apa yang menjadi tujuan hidupnya dan tidak memiliki kebebasan dalam bertindak. Nilai seringkali datang dari pengalaman masa lalu, seperti bagaimana ia dan lingkungan sekitarnya menilai tentang kegiatan menyusui. Jika lingkungan sekitarnya menyusui maka orang tersebut cenderung memiliki penilaian positif mengenai menyusui, tapi jika orang tersebut lebih sering melihat keluarga atau orang terdekatnya memberikan dot berisi susu formula maka orang tersebut merasa tidak ada yang salah atau aneh jika tidak menyusui. Ibu iit Ardiansyah menyusui anak pertama dan kedua, karena itu ketika ia mengalami kegagalan saat menyusui anak ketiganya ia berusaha untuk kembali menyusui. Berbeda dengan ibu Rista, awalnya ia merasa tidak ada yang keliru jika tidak menyusui bayinya dan tidak ada tentangan dari lingkungan terdekatnya. Baru ketika anaknya menunjukan gejala-gejala alergi pada susu formula ia mencari informasi mengenai menyusui dan memutuskan untuk kembali menyusui.

Kepercayaan adalah komponen kognitif dari faktor sosiopsikologis. Kepercayaan disini tidak ada hubungannya dengan hal-hal gaib, tetapi adalah keyakinan bahwa sesuatu itu "benar" atau "salah" atas dasar bukti, sugesti otoritas, pengalaman atau intuisi (Hohler, 1978 dalam Rakhmat 2005: 42). Kepercayaan menberikan gambaran pada manusia dalam mempersepsi kenyataan, memberikan dasar bagi pengambilan keputusan, dan menentukan sikap terhadap objek sikap. Jika klien percaya bahwa susu formula membuat bayi lebih pintar dan menyusui hanya untuk proses bonding, maka sikapnya akan negatif terhadap anjuran untuk memberikan ASI selama dua tahun atau jika ada yang mengatakan sebaliknya. Kepercayaan yang diyakini oleh para konselor bahwa ASI adalah yang terbaik bagi bayi usia 0-2 tahun tidak hanya berdasarkan asumsi, tapi dari hasil penelitian para ahli yang mereka baca dan pelajari. Interaksi dua arah antara konselor dengan klien, salah satunya bertujuan untuk memberikan pengetahuan dan menularkan keyakinan yang dimiliki konselor kepada klien, agar klien memiliki kepercayaan yang sama mengenai ASI.

Untuk dapat mengetahui sikap, kebutuhan, nilai, dan kepercayaan yang diyakini oleh klien diperlukan keterampilan untuk mengorek informasi. Keterampilan komunikasi juga dibutuhkan oleh konselor untuk membantu klien mengatasi kendala mereka saat menyusui. Karena itulah keterampilan menggunakan teknik-teknik komunikasi harus dimiliki konselor, teknik komunikasi tersebut tidak bisa hanya dipelajari tapi harus dilakukan terus menerus agar semakin ahli. Manusia cenderung menyenangi orang-orang yang memiliki kemampuan lebih tinggi darinya, dan lebih berhasil dalam kehidupannya. Oleh karena itu, penting bagi konselor untuk memiliki 
keahlian dalam ilmu breastfeeding dan juga ilmu bagaimana cara berkomunikasi yang baik. Seseorang yang telah mempelajari ilmu menyusui tapi tidak menguasai komunikasi akan sulit menyampaikan informasi pada kliennya, begitupula sebaliknya seseorang yang ahli komunikasi tapi tidak memiliki pengetahuan ilmu menyusui bisa menyesatkan klien dengan informasi yang salah.

Kepedulian klien mengenai issue menyusui amat mempengaruhi seberapa cepat klien akan menerima informasi dari konselor. Karena manusia memiliki kecenderungan untuk melihat apa yang ingin ia lihat dan mendengar apa yang ingin ia dengar. Bagi orang kebanyakan issue mengenai relaktasi tentu tidak begitu menarik perhatian, tapi bagi perempuan yang memiliki bayi tapi tidak dapat menyusui ini menarik karena issue ini erat kaitannya dengan kehidupannya.

Komunikasi yang terjadi antara konselor dengan klien adalah komunikasi antarpribadi yang bertujuan untuk kesehatan. Kata kunci dari komunikasikesehatan adalahmenginformasikan dan mempengaruhi keputusan, memotivasi seseorang, merubah perilaku, meningkatkan pengetahuan, pemahaman mengenai masalah kesehatan, memberdayakan masyarakat. Komunikasi ini berlangsung secara tatap muka,dimana proses pertukaran informasi dilakkukan dengan dialog dua arah. Sifat komunikasi antar pribadi memiliki potensi yang lebih besar dalam proses perubahan sikap dibandingkan dengan komunikasi lainnya.

Komunikasi terapeutik sebagai bagian dari komunikasi antar pribadi menjadi bagian dari proses konseling yang sedang dijalankan sehingga diharapkan mampu mempercepat proses penyelesaian masalah klien terutama dari sisi psikologi/kejiwaan. Konselor harus bisa membuat klien mengungkapkan pikiran dan perasaannya berkaitan dengan menyusui untuk diamati dan dianalisis, untuk mengetahui apa yang menjadi permasalahan dan kekhawatiran klien. Konselor dan klien secara bersama-sama memperbaiki hubungan komunikasi mereka menjadi komunikasi dua arah yang saling mendukung demi tujuan bersama.

Ada beberapa prinsip dasar yang harus dipahami dalam membangun dan mempertahankan hubungan yang terapeutik. Pertama, hubungan konselor dan klien adalah hubungan terapeutik yang saling menguntungkan. Hubungan ini didasarkan pada prinsip "humanity of nurse and client Kedua, konselor harus menghargai keunikan klien. Konselor harus memahami perasaan dan perilaku klien dengan melihat frame of reference dan field of experience klien yang berbedabeda. Ketiga, semua bentuk komunikasi yang dilakukan harus tetap menjaga harga diri masingmasing, baik konselor maupun klien. Keempat, komunikasi yang menciptakan tumbuhnya saling percaya (trust) harus dicapai terlebih dahulu sebelum menggali permasalahan dan memberikan alternative pemecahan masalah (Stuart \& Sundeen 1991, dalam Suryani 2005: 14).

Penelitian ini menggunakan teori interaksi symbolic dari George Herbert Mead (18631931). Interaksi simbolik pada intinya menjelaskan tentang kerangka referensi untuk memahami bagaimana manusia, bersama dengan orang lain, menciptakan dunia simbolik dan bagaimana cara dunia membentuk perilaku manusia. Interaksi simbolik ada karena ide-ide dasar dalam membentuk makna yang berasal dari pikiran manusia (Mind) mengenai diri (Self), dan hubungannya di tengah interaksi sosial, dan tujuan bertujuan akhir untuk memediasi, serta menginterpretasi makna di tengah masyarakat (Society).

Teori Interaksi Simbolik dirasa cocok sebagai perspektifdalammenganalisis fenomena kasus komunikasi terapeutik yang dilakukan konselor laktasi. Karena selama interaksi terjadi antara konselor dengan klien terjadi pertukaran simbol dan lambang-lambang baik verbal maupun nonverbal yang disampaikan dan ditangkap dengan lima pancaindra. Pada tahap ini terjadi proses mental atau proses berfikir bagi manusia sebelum ia bertindak. Karena menurut teori interaksi simbolik tindakan manusia itu bukan stimulus-respon melainkan stimulus-proses berfikir-respon. Stimulus yang disampaikan konselor kemudian akan diproses dalam pikiran (mind) konselor dan klien, proses ini disebut proses berfikir. Berfikir dilakukan seseorang untuk memahami realitas dalam rangka mengambil keputusan, memecahkan persoalan, atau memikirkan sesuatu yang baru. Proses berfikir ini sangat dipengaruhi konsep diri klien (self concept), karena konsep diri mempengaruhi apakah klien itu bersedia membuka diri dan bagaimana klien akan mempersepsi pesan. Klien dengan konsep 


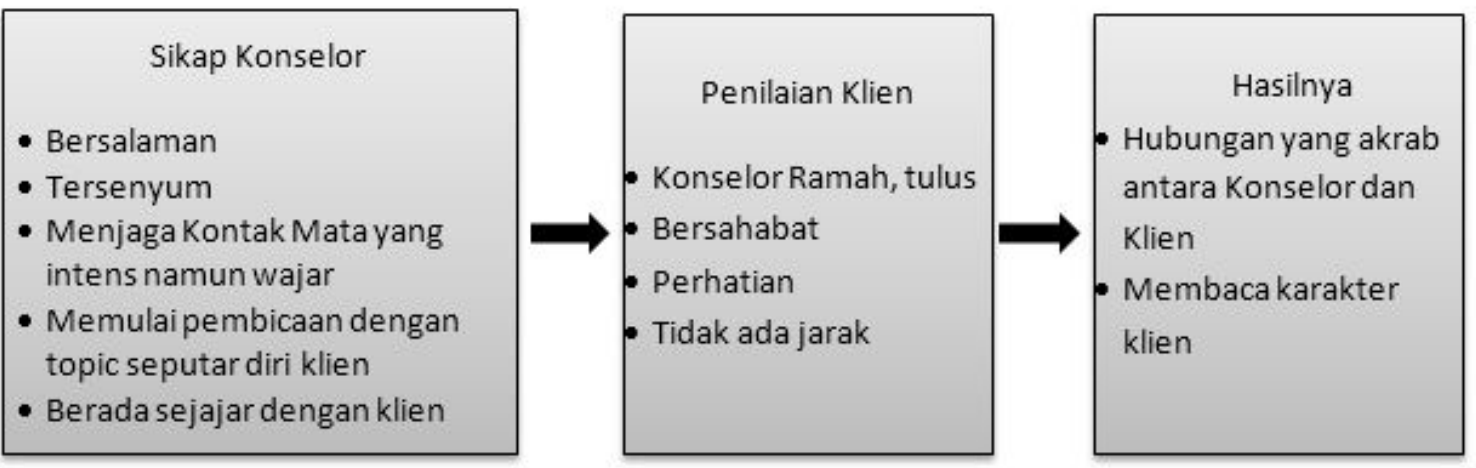

Gambar 2 Tahap Pembinaan Hubungan Baik

diri negative cenderung peka terhadap kritik dan bersikeras mempertahankan pendapatnya yang salah, ia juga bersikap pesimis terhadap kemampuan dirinya. Karena itu konselor perlu memiliki kemampuan komunikasi untuk bisa memberikan motivasi pada klien sehingga klien memiliki keyakinan bahwa ia memiliki kemampuan untuk mengatasi masalahnya sendiri.

Konsep individu biologis dimaknai oleh Mead sebagai individu yang polos dan belum mendapatkan pengaruh apa-apa dari lingkungannya. Dan ketika individu itu mulai memasuki wilayah masyarakat yang mikro, maka individu itu akan terpengaruh dalam perilakunya. Untuk itu konselor juga harus menciptakan lingkungan yang mendukung usaha klien untuk menyusui, dimulai dari lingkungan terdekat seperti suami, asisten rumah tangga, orang tua, saudara dan lain sebagainya. Dukungan dari masyarakat bisa diciptakan dengan mendekatkan klien dengan organisasi pendukung ibu menyusui atau ibu menyusui lainnya. Sehingga klien merasa bahwa menyusui adalah hal yang baik, bernilai positif, dan umum untuk dilakukan.

Dalam komunikasi terapeutik terdapat tahapan-tahapan yang harus dilewati, karena seseorang tidak menjadi teman akrab segera setelah pertemuan terjadi, karena keakraban tumbuh secara bertahap. Dan hal yang sama barangkali berlaku pula untuk kebanyakan hubungan lainnya seperti hubungan antara konselor dan kliennya. Berdasarkan hasil observasi di lapangan dan wawancara dengan para informan peneliti menyederhanakan tahapan komunikasi yang berlangsung antara konselor dan klien kedalam tiga tahapan, yaitu:

1. Tahap pembinaan hubungan baik

2. Tahap pengumpulan informasi

3. Tahap pemecahan masalah
Hubungan yang intim antara konselor dan klien dibutuhkan selama proses konseling laktasi berlangsung. Karena itu peneliti menyimpulkan bahwa tahap pertama dalam komunikasi terapeutik adalah tahap pembinaan hubungan baik. Pada tahap pertama ini konselor membuat kontak. Ada beberapa macam persepsi alat indra yang berlaku di tahap ini yaitu penglihatan, pendengaran, dan penciuman. Menurut beberapa periset, selama tahap inilah -dalam empat menit pertama interaksi awal, anda akan memutuskan apakah anda ingin melanjutkan hubungan atau tidak. Pada tahap ini konselor berusaha menciptakan kesan ramah, hangat, bersahabat, setara dan terbuka.

Dari hasil wawancara dan observasi dengan para informan disimpulkan ada 5 sikap positif yang ditunjukan oleh konselor laktasi saat berkenalan dengan klien.

Kelima sikap ini simbol-simbol yang biasanya ditunjukan seseorang saat bertemu dengan orang lain, untuk menunjukan sikap ramah dan bersahabat. Kontak mata adalah salah satu sistem pesan nonverbal yang paling penting. Kontak mata memungkinkan klien menyadari penerimaan konselor terhadap diri klien beserta pesan-pesan dan keluhan-keluhan yang disampaikan klien. Bagi konselor penting sekali untuk memperhatikan kontak mata dengan klien, karena kontak mata dengan klien akan mengisyaratkan hubungan.

Setiap anggota badan seperti wajah, tangan, kepala, kaki, dan anggota tubuh secara keseluruhan dapat digunakan sebagai isyarat simbolik saat berkomunikasi. Bahasa tubuh konselor akan tetap dimaknai oleh klien meskipun ia sedang tidak berbicara. Saat konselor bertemu dengan klien posisi berdiri klien saat bersalaman yang agak condong kedepan, menunjukan ketertarikan dan keramahan. Ketika duduk konselor duduk 


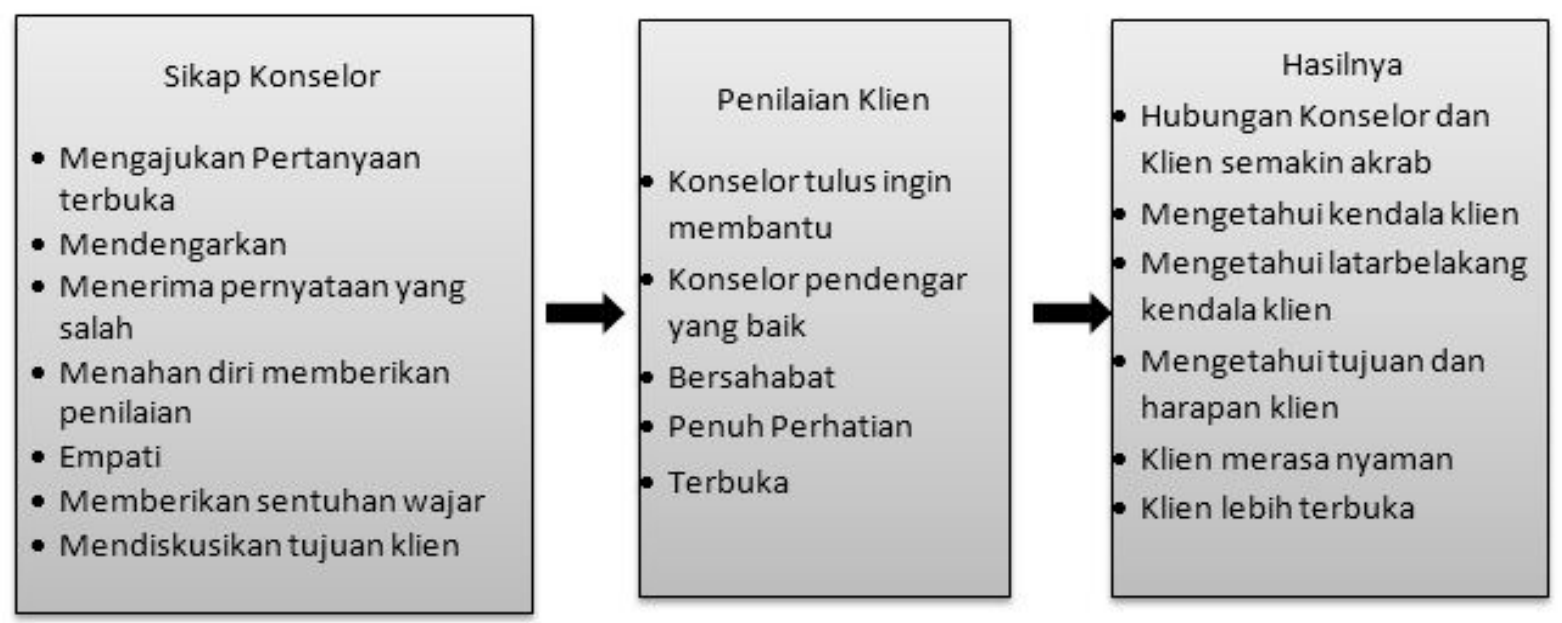

Gambar 3 Tahap Pengumpulan Informasi

tidak menyender dan dengan posisi badan yang condong kearah klien, terutama saat klien sedang berbicara diikuti dengan gerakan kepala yang mengangguk-angguk menandakan perhatian dan bahwa konselor melibatkan diri secara penuh dalam pembicaraan klien. Saat duduk konselor pun tidak mengangkat dan menyilangkan kakinya sebagai bentuk kesopanan. Posisi tangan pun terbuka tidak disilangkan atau tangan yang bersidekap karena dapat menggambarkan ketertutupan atau sikap bertahan.

Tahap kedua dalam proses komunikasi terapeutik antara klien dan konselor adalah tahap pengumpulan informasi. Pada tahap ini konselor berusaha mengetahui masalah dan kendala menyusui yang dihadapi klien sehingga ia membutuhkan bantuan konselor. Pengumpulan informasi merupakan tugas utama konselor. Pendalaman masalah yang dihadapi klien, latar belakang situasi dan kondisi klien, perasaan dan kebutuhan klien serta pemahaman klien terhadap masalah yang dihadapinya, hal ini berguna untuk memberikan arah dan tujuan konseling dan menghindari pembahasan topik yang tidak berguna. Pada tahap ini teknik komunikasi konselor diuji, seperti teknik mendengarkan, mengajukan pertanyaan, menunjukan empati, dan bagaimana mendiskusikan tujuan.

Menurut dr. Utami Roesli (69 tahun) kendala ibu menyusui dikarenakan kurang percaya diri, karena didasarkan pada pendapat klien yang keliru mengenai menyusui. Hal ini kareja masih banyak mitos yang beredar dimasyarakat dan kurangnya pengetahuan ibu mengenai menyusui. Kurangnya kepercayaan diri klien pada kemampuannya untuk menyusui, membuat klien menjadi pribadi yang tidak menyenangi dirinya sendiri, ia memiliki kecenderungan merasa gagal sebagai seorang ibu. Padahal, produksi ASI berkaitan dengan hormone oksitosin yaitu hormone yang akan bekerja dengan baik jika individu dalam keadaan gembira dan rileks.

Tugas konselor pada tahap ini adalah mencari tahu apa yang menyebabkan klien merasa tidak percaya diri. Mencari informasi sebanyak-banyak mengenai latarbelakang klien, sikap, kebutuhan, nilai-nilai yang dianut, kepercayaan dan seberapa besar kepedulian klien dan bagaimana lingkungan membentuk kerangka berfikir klien mengenai issue menyusui.

Teori self disclosure menjelaskan bagaimana pengungkapan diri berkaitan erat dengan aspek keakraban yakni sejauh mana derajat informasi mencerminkan orang yang bersangkutan secara personal atau pribadi atau perasaan-perasaan yang paling dalam dari diri (Rakhmat, 2005: 262). Teori ini menjelaskan ada empat sel dalam diri manusia, yang pertama yaitu open area, berisi informasi tentang diri yang diketahui oleh orang lain seperti nama, alamat, umur, pekerjaan, pendidikan terakhir, dan lain sebagainya. Ketika memulai suatu hubungan konselor akan memulai dengan berbicara mengenai topik-topik netral seperti informasi tentang diri yang umum ini. Dari sana sedikit banyak konselor akan mengetahui latarbelakang pribadi klien.

Yang kedua adalah hidden area, berisi informasi mengenai diri kllien yang diketahui 
oleh klien tapi tertutup untuk orang lain. Saat pertama kali bertemu dengan orang baru, hidden area lebih besar dari open area, seiring dengan semakin intens interaksi dan komunikasi antar individu hidden area akan semakin kecil. Tugas konselor pada tahap ini adalah memperkecil hidden area dengan mengumpulkan informasi sebanyak-banyaknya mengenai klien. jika klien tidak mau berbagi mengenai hidden area artinya tingkat kepercayaan klien pada konselor masih rendah dan ini berpengaruh pada terhambatnya proses komunikasi terapeutik.

Daerahyang ketigaadalahblindarea, daerah ini tidak diketahui individu tapi diketahui orang lain. Contohnya ilmu mengenai menyusui dan fakta sebenarnya dari mitos-mitos yang beredar dimasyarakat, mungkin klien tidak mengetahui tapi konselor mengetahuinya. Dengan mendapatkan masukan dari konselor blind area klien akan semakin berkurang. Semakin klien dapat memahami fakta mengenai menyusui, maka akan semakin mudah klien melakukan upaya-upaya untuk kembali menyusui. Daerah uang terakhir unknow area adalah informasi yang baik orang lain maupun individu tersebut tidak mengetahuinya.

Pada umumnya semakin luas daerah terbuka klien semakin meningkat pula kesadaran dirinya. Dengan mendiskusikan apa yang klien rasakan dan alami pada konselor, kemungkinan besar klien akan melihat lebih jelas apa yang selama ini tidak tampak olehnya. Dengan bantuan umpan balik dari dari konselor, klien akan mendapat pandangan dan pemikiran baru yang membantunya menemukan pemecahan masalah yang dia alami saat ini. Hal inilah yang diharapkan dalam program konseling, dengan kemampuan komunikasi, konselor membantu klien untuk memutuskan apa yang terbaik untuk dirinya.

Tahap terakhir dalam proses komunikasi terapeutik konselor dengan klien relaktasi adalah tahap penyelesaian masalah. Tahap ini merupakan tahap inti dari keseluruhan proses komunikasi terapeutik. Pada tahap ini konselor dan klien bersama-sama mencoba mencari alternative untuk mengatasi kendala klien dalam menyusui. Konselor mencoba meningkatkan wawasankliendenganmenghubungkanpersepsi, pikiran, perasaan, dan tindakan. Pemahaman ini harus dapat diterjemahkan ke dalam tindakan yang terintegrasi ke dalam kehidupan seharihari klien. Konselor membantu klien untuk dapat menguasai kecemasan, meningkatkan kemandirian dan tanggung jawab pribadi. Perubahan perilaku adalah tujuan sebenarnya dari fase hubungan ini, termasuk meningkatkan kepercayaan diri klien dan memberi dukungan agar klien terus menyusui

Padatahapinidilakukan 5 teknik komunikasi yang harus dikuasai konselor yaitu, menerima, menerima pendapat dan pikiran klien meskipun itu salah; mengenali dan memuji, memberi penilaian positif pada apa yang klien lakukan dengan benar untuk meningkatkan kepercayaan dirinya; memberikan bantuan, memberi bantuan kongkrit mengenai bagaimana cara menyusui dan manajemen laktasi; memberi informasi yang relevan dengan bahasa yang sederhana; terakhir adalah memberi satu dua saran yang dibutuhkan klien.

Hubungan konselor dan klien yang terapeutik tidak mungkin dapat dicapai tanpa komunikasi. Menurut Stuart dan Sundeen (1991: 22) tujuan hubungan terapeutik yang diarahkan kepada pertumbuhan klien meliputi: Meningkatkan realisasi penerimaan diri, dalam hal ini penerimaan diri dan rasa hormat

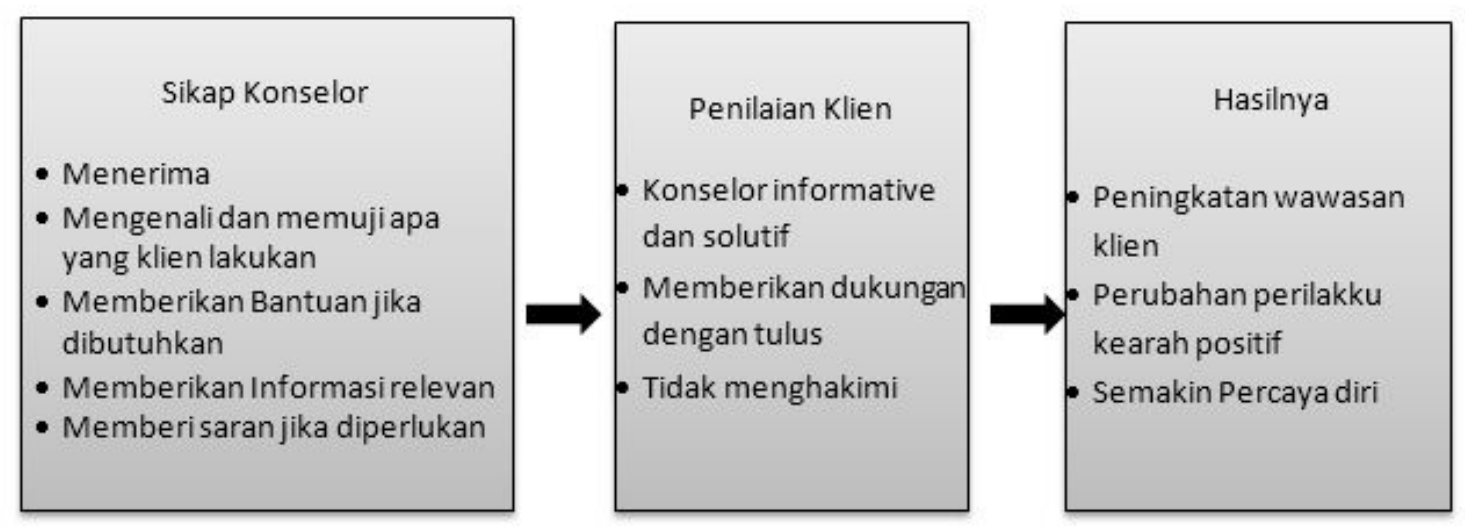


terhadap diri sendiri, meningkatkan identitas dan integritas diri, identitas diri yang jelas dan rasa saling percaya harus dikembangkan, integritas yang tinggi diperlukan untuk dapat berkembang menjadi pribadi yang sehat, meningkatkan kemampuan untuk membina hubungan interpersonal yang intim, adanya rasa saling ketergantungan dan mencintai, juga diperlukan untuk membina pribadi yang sehat.

Peningkatan fungsi dan kemampuan,

yaitu kemampuan untuk memuaskan kebutuhan serta mencapai tujuan personal yang realistis yang berhubungan dengan fungsi-fungsi tubuh. Stuart dan Sundeen (1991: 22)

Untuk dapat lebih mengerti hubungan antara ketiga tahapan komunikasi terapeutik dan hubungannya dengan teknik komunikasi terapeutik yang dilakukan konselor laktasi akan digambarkan sebagai berikut:

Dari hasil penelitian di lapangan diketahui bahwa ada tiga tahapan dalam proses komunikasi terapeutik yang dilakukan konselor laktasi pada klien relaktasi. Ketiga tahapan tersebut memiliki langkah-langkah dan tujuan tersendiri. Kesuksesan tiap tahapnya berpengaruh pada proses komunikasi di tahap selanjutnya.

Manusia pada dasarnya adalah unik yang memiliki kecenderungan untuk berfikir rasional dan irasional. Ketika berpikir dan bertingkahlaku rasional manusia akan efektif, bahagia dan kompeten. Sebaliknya jika manusia mulai berfikir dan bertingkahlaku irasional maka ia tidak akan efektif. Hambatan psikologi adalah akibat dari cara berfikir yang tidak logis dan irasional yang sebagian besar disebabkan oleh evaluasi, interpretasi dan filosifi yang disadari maupun tidak disadari. Berfikir irasional diawali dengan belajar secara tidak logis yang diperoleh dari orang tua dan budaya tempat dibesarkan.

Menyusui adalah kegiatan yang sudah dilakukan perempuan dari berjuta-juta tahun yang lalu. Cerita tentang bagaimana cara menyusui dan cara mengatasi kendala menyusui diceritakan dari generasi ke generasi. Menyusui menjadi kegiatan yang sangat sensitf dan amat personal, tidak semua orang bisa bebas berbicara mengenai kegiatan ini karena menyangkut bagian intim dari tubuh perempuan. Mungkin hanya dengan sesama perempuan, antara ibu dan anak perempuannya, atau dengan sesama teman perempuannya. Karena kegiatan ini jarang dibahas diruang public, maka fakta dan mitos mengenai menyusui menjadi kabur. Meski di era informasi masyarakat mendapat kemudahan mengakses informasi, tapi masih banyak orang meyakini mitos-mitos mengenai menyusui, karena dianggap sebagai nasehat orang tua. Pandangan irasional ini yang kemudian banyak menghambat ibu untuk bisa menyusui bayinya secara eksklusif atau hingga usia bayinya dua tahun sesuai anjuran pemerintah, WHO dan Unicef.

Tujuan konseling laktasi adalah memperbaiki dan mengubah sikap, persepsi, cara berfikir, keyakinan serta pandanganpandangan klien yang keliru dan tidak logis menjadi pandangan yang benar dan logis agar klien dapat memutuskan dengan sadar yang terbaik baginya. Untuk menghilangkan pandangan keliru dan tidak logis yang merusak percaya diri dan motivasi klien untuk bisa menyusui konselor membutuhkan strategi dan teknik yang tepat.

Teknik komunikasi yang digunakan konselor laktasi didasarkan pada upaya konselor untuk menghapus pendapat klien yang salah dengan memberi klien informasi yang benar. Dengan begitu klien dengan sendirinya akan menghilangkan pendapat yang salah dan memiliki keyakinan baru yang didasarkan pada kebenaran. Keyakinan baru itu adalah bahwa ASI makanan terbaik bagi bayi dan tidak ada alasan bagi ibu untuk tidak memberikan yang terbaik bagi bayinya.

Sikap komunikasi antarpribadi yang berpotensi lebih besar dalam proses perubahan sikap dibandingkan komunikasi yang lain. Karena itu kecenderungan teknik yang digunakan dalam komunikasi terapeutik adalah komunikasi antar pribadi.

Hubungan yang terapeutik adalah hubungan yang mana seorang anggota dengan sengaja menggunakan keterampilan interaksi untuk memberikan semangat dan mendukung perubahan-perubahan diri anggota lainnya. Setiap langkah dalam tahapan komunikasi terapeutik yang dilakukan konselor senantiasa berorientasi kepada klien. Maksudnya adalah selama konseling terjadi konselor selalu berusaha menyesuaikan diri dengan klien. Konselor mengkomunikasikan orientasinya pada klien secara nonverbal melalui kontak mata yang terpusat, senyum, anggukan kepala, mencondongkan tubuh kearah klien, dan memperlihatkan perasaan serta emosi 


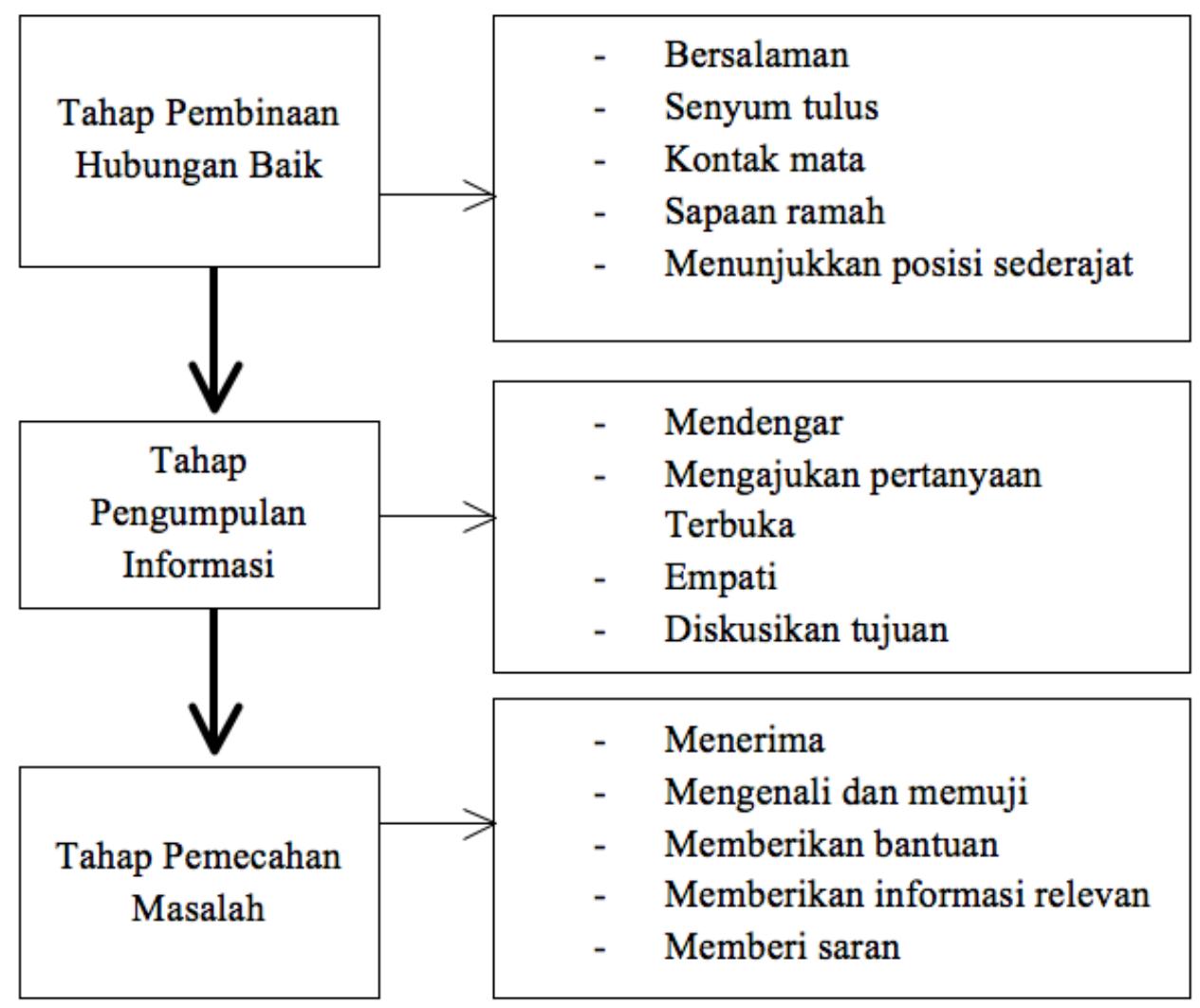

Gambar 5 Proses Komunikasi Terapeutik dan Teknik yang dilakukan Konselor Laktasi

melalui ekspresi wajah yang sesuai. Secara verbal konselor memperlihatkan minat melalui komentar sederhana seperti "Oh" dan "Hm", melalui permintaan akan informasi lebih jauh "apa yang anda lakukan saat itu?", dan melalui ungkapan empati dan pujian.

Untuk dapat menjalankan proses komunikasi terapeutik secara efektif, konselor perlu menguasai teknik-teknik komunikasi. Konselor perlu memahami bahwa keterampilan komunikasi tidak hanya dalam berntuk verbal tapi juga nonverbal, karena keduanya saling berkaitan dan saling memperkuat pesan yang disampaikan. Adakalanya komunikasi verbal dan nonverbal saling bertentangan. Keterampilan komunikasi merupakan kompetensi utama sebagai konselor laktasi.

Isyarat nonverbal yang dianggap paling oleh para ahli komunikasi adalah isyarat mata. Esthetika Wulandari (40 tahun) mengatakan bahwa mata adalah jendela hati yang menggambarkan perhatian dan keramahan.

"contohnya mata, mata kan katanya jendela hati jadi bagaimana kita bikin agar mata kita nih bisa bicara, tunjukan perhatian dan keramahan pada orang itu." Pesan-pesan yang dikomunikasikan oleh mata bervariasi bergantung pada durasi, arah, dan kualitas dari perilaku mata. Contohnya bila kontak mata terjadi lebih singkat, kita dapat mengira orang ini tidak berminat, malu, atau sibuk. Bila waktunya agak lama, kita umumnya menganggap hal ini menunjukan minat yang berlebihan. Arah pandangan mata juga mengkomunikasikan sesuatu, seperti kegugupan selama interaksi, minat yang besar atau minat yang rendah, rendah diri dan sebagainya.

Mark Knap (1978) seperti dikutip dalam DeVito (1997: 191), mengemukakan empat fungsi komunikasi mata. Fungsi komunikasi mata yang pertama adalah mencari umpan balik, yang kedua kontak mata berfungsi untuk menginformasikan pihak lain untuk berbicara, mata juga mengisyaratkan sifat hubungan dan fungsi yang terakhir adalah mengkompensasi bertambahnya jarak fisik.

Dalam konseling relaktasi konselor sering melakukan kontak mata dengan klien baik saat berbicara maupun saat mendengarkan. Kontak mata dilakukan konselor untuk mengisyaratkan sifat hubungan positif yang ditunjukan dengan pandangan yang terfokus yang penuh perhatian. 
Parabahasa adalah cara bagaimana orang mengucapkan lambing-lambang verbal. Jadi, jika petunjuk verbal menunjukkan apa yang diucapkan, petunjuk parabahasa mencerminkan bagaimana mengucapkannya. Isyarat ini sangat penting untuk menunjukan emosi dan membantu menyampaikan informasi. Menurut Joseph A. Devito (2007:213) Manusia memiliki kecenderungan untuk menilai segala sesuatu. Kita cepat sekali membuat penilaian (judgement) tentang kepribadian orang lain berdasarkan petunjuk-petunjuk paralinguistik. Penilaian tersebut kadang benar kadang juga salah. Untuk itu, sebagai konselor ada baiknya memanfaatkan penilaian paralingustik yang diberikan klien. Dengan berbicara dengan tidak pelan dan tidak terlalu keras, karena dengan berbicara terlalu pelan orang akan cenderung menilai kita tidak percaya diri tapi berbicara terlalu keras orang akan menilai kita memiliki ego yang berlebihan. Orang yang berbicara tanpa alunan nada alias datar tentu akan membosankan bagi yang mendengarkan, sehingga informasi yang disampaikan tidak sampai dengan baik.

Teknik parabahasa penting dikuasai konselor untuk menunjukan emosi dan membantu menyampaikan informasi. Teknik parabahasa yang disampaikan dr. Utami Roesli, bahwa penerimaan pesan dengan menggunakan irama berbicara (voice tone) dan gesture akan diterima lebih baik dari pada hanya kata-kata. Seperti yang dikemukakan beliau sebagai berikut:

"Misalnya saya bilang "Reta saya haus" (dengan intonasi datar) itu penerimaannya 7\%, dengan pitch control "Retaaa.. saya haus!" diterima $33 \%$, dan dengan pitch control plus body language "Retaa.. saya haus (sambil memegang tenggorokan) itu akan diterima $55 \%$. Dengan menggunakan voice tone dan body language."

Isyarat nonverbal lain adalah bahasa tubuh termasuk didalamnya tiga komponen utama yaitu pesan fasial, pesan gestural dan pesan postural. Pesan fasial menggunakan mimik wajah menyampaikan makna kebahagiaan, rasa terkejut, ketakutan, kemarahan, kesedihan, kemuakan, pengecaman, minat, ketakjuban dan tekad (Rakhmat, 2005:289). Dalam konseling relaktasi konselor menggunakan pesan fasial untuk menunjukan ekspresi senang dan tak senang, menunjukan minta terhadap pembicaraan klien, dan mengkomunikasikan adanya atau kurangnya pengertian terhadap pesan yang disampaikan klien. Mimik wajah kombinasi antara minat dan tekad ditunjukan saat konselor menyampaikan informasi penting bagi klien. Sedangkan mimic wajah sedih ditunjukan konselor saat menunjukan empatinya.

Pesan postural berkenaan dengan keseluruhan anggota badan. Postur yang condong kearah klien adalah cara konselor menunjukan kesukaan dan penilaian positif pada klien. Posisi badan sejajar dengan klien untuk mengkomunikasikan bahwa konselor dan klien setara, tidak ada yang lebih tinggi atau lebih tahu dibandingkan yang lainnya. Konselor menunjukan pesan postural dengan bersikap respopnsif terhadap apa yang disampaikan klien, menunjukan perubahan mimic muka, menggerakan tangan dan mengubah posisi badan saat berinteraksi.

Penggunaan isyarat ruang mengungkapkan sejelas dan seakurat kata-kata dan kalimat. Konselor yang berada dekat dengan klien, dengan tangan berada di bahu klien dan mata menatap langsung kepada klien mengkomunikasikan sesuatu yang sangat berbeda dengan konselor yang berada berseberangan dengan klien dan terhalang meja dengan tangan terlipat didada. Edward T. Hall (1959, 1966) seperti dikutip dalam DeVito (1997:197-198) membedakan empat macam jarak yang menurutnya menggambarkan macam hubungan yang dibolehkan. Seperti jarak intim, mulai dari fase dekat (bersentuhan) sampai ke fasa jauh sekitar 15 sampai $45 \mathrm{~cm}$. Pada fasa ini kehadiran seseorang sangat jelas sehingga masing-masing pihak dapat mendengar, mencium, dan merasakan nafas yang lain. Yang kedua jarak pribadi. Fase dekat jarak pribadi antara 45-75 cm, pada jarak ini seseorang masih bisa menyentuh dan memegang tetapi hanya dengan mengulurkan tangan. Bila ruang pribadi diganggu, mereka merasa tidak nyaman dan tegang. Tapi bila ruang pribadi individu dimasuki orang yang dikenal atau disukai maka individu tersebuut tidak akan merasa tegang atau tidak nyaman. Yang ketiga Jarak sosial. Fasa dekatnya dari 120 sampai $210 \mathrm{~cm}$ adalah jarak yang biasanya digunakan bila melakukan pertemuan bisnis dan interaksi pada pertemuan yang bersifat sosial. Yang terakhir adalah jarak public. Pada fasa dekat dari jarak public adalah 
360 sampai $450 \mathrm{~cm}$. Pada jarak ini seseorang dapat mengambil tindakan defensive bila terancam, karena telindungi oleh jarak.

Winston Churchill seperti dikutip dalam Mulyana (2002: 362), mengatakan bahwa kenyamanan peserta komunikasi dipengaruhi penataan ruangan kursi dan meja di ruangan tersebut. Penataan furniture jelas mempengaruhi suasana komunikasi. Maulana juga menjabarkan hasil penelitian informal yang dilakukan Dokter Abraham White mengenai apakah meja yang membatasi dokter dan pasiennya mempengaruhi konsultasi mereka, hasilnya adalah 55,4\% pasiennya duduk lebih santai saat meja dihilangkan. Bila meja itu berada pada tempatnya hanya $10,8 \%$ dari pasiennya yang duduk santai.

Maka masuk akal jika dalam konseling relaktasi perlunya menghilangkan pembatas seperti meja saat konseling. Secara simbolik hal ini menunjukan bahwa tidak ada batasan antara konselor dan klien. Dengan begitu komunikasi dua arah pun akan lebih lancar

Komunikasi sentuhan, yang juga dinamai haptik (haptics), menurut Montague (1971) dikutip oleh DeVito (1997:203), merupakan bentuk komunikasi yang paling primitive. Sentuhan adalah suatu perilaku nonverbal yang multi-makna, dapat menggantikan seribu kata. Banyak riset menunjukan bahwa orang berstatus tinggi lebih sering menyentuh oranng bertsatus rendah dari pada sebaliknya. Sentuhan tidak bersikap acak, melainkan strategi komunikasi yang penting.

Menurut Helsin dalam Mulyana (2002: 336), terdapat lima kategori sentuhan, yang merupakan suatu rentang dari yang sangat impersonal hingga yang sangat personal. Kategori-kategori tersebut adalah sebagai berikut:

Fungsional professional. Disini sentuhan bersifat "dingin" dan berorientasi bisnis, misalnya pelayan toko yang membantu pelanggan memillih pakaian

Sosial sopan. Perilaku dalam situasi ini membangun dan memperteguh penghargaan, aturan dan praktik sosial yang berlaku, misalnya berjabat tangan

Persahabatan kehangatan. Kategori ini meliputi setiap sentuhan yang menadakan afeksi atau hubungan yang akrab, misalnya dua orang sahabat yang saling merangkul.

Cinta keintiman. Kategori ini merujuk pada sentuhan yang menyatakan keterikatan emosional atau ketertarikan, misalnya mencium pipi orang tua dengan lembut.

Rangsangan seksual. Kategori ini berkaitan erat dengan kategori sebelumnya hanya saja motifnya bersifat seksual. Rangsangan seksual tidak otomatis bersifat cinta atau keintiman.

Kriger (1975) seperti dikutip yang Stuart (1991:35), telah mengembangkan konsep "terapi sentuhan", dengan meletakkan tangan perawat pada atau dekat dengan tubuh orang yang sakit untuk tujuan membantu atau penyembuhan. Kriger percaya sentuhan dizinkan dalam keperawatan dan menghasilakan efek terapi, efek menenangkan dari sentuhan sering diabaikan. Sentuhan merupakan aspek universal dan dasar dari semua hubungan perawat-pasien. Hal ini sering digambarkan sebagai sarana pertama dan paling dasar dalam komunikasi.

Penggunaan isyarat sentuhan dalam komunikasi terapeutik antara konselor dan klien tidak bersifat acak, melainkan adalah sebuah strategi komunikasi yang penting. Sentuhan yang digunakan diantara sentuhan yang bersifat social dan sopan seperti berjabat tangan dan saling menempelkan pipi. Sentuhan yang bersifat persuasi seperiti saat Canriyana mencoba meyakinkan Ibu Iit Ardiansyah agar klien terus mencoba menyusui dan jangan menyerah. Dan sentuhan yang menunjukan persahabatan dan kehangatan, seperti menepuk dan mengusap bahu yang dilakukan Nia Umar saat Ibu Rista Pikatan menangis tersedu.

Keterampilan komunikasi lainnya adalah keterampilan mendengarkan. Mendengarkan adalah aktivitas yang tidak bisa lepas dari keseharian manusia, mulai dari bangun tidur hingga tidur lagi, baik disengaja maupun tidak disengaja. Berdasarkan hasil penelitian yang dilakukan Rankin (1929) yang dikutip DeVito (1997: 93) manusia menghabiskan 45\% waktunya untuk mendengarkan, 30\% untuk berbicara, 16\% untuk membaca dan $9 \%$ untuk menulis.

Ada tiga jenis mendengarkan menurut

DeVito (1997:94)

Mendengarkan untuk kesenangan

Mendengarkan untuk informasi

Mendengarkan untuk Membantu

Konselor mendengarkan apa yang disampaikan klien dengan tujuan untuk 
membantu. Konselor menndengarkan klien mengeluh, membicarakan suatu masalah, atau berusaha untuk mengambil keputusan. Bantuan yang diberikan bisa dalam bentuk saran atau nasehat bisa juga sekedar menjadi pendengar yang perhatian dan mendukung.

Langkah pertama untuk meningkatkan keterampilan mendengarkan adalah dengan mengenali dan memerangi berbagai hambatan dalam mendengarkan yang efektif seperti yang ditulis Nichols (1961) seperti dikutip DeVito (1997:95).

Sibuk dengan diri sendiri

Nia Umar (36 taun) menyampaikan "Memang harus memfokuskan diri ketika kita mau konseling ya gak boleh mikirin yang lain, handphone jauh-jauh, bener-bener hanya melihat ibunya."

Hal ini rupanya sesuai dengan pendapat Nichols, bahwa penghambat paling serius dan paling merusak mendengarkan yang efektif adalah kecenderungan individu untuk menjadi sibuk dengan diri sendiri. Karena itu para konselor sengaja menjauhkan atau mematikan handphone pada saat konseling agar konseling tidak terganggu.

Sibuk dengan masalah-masalah ekternal

Penghambat lain adalah kecenderungan untuk memusatkan perhatian pada masalah-masalah yang tidak relevan dengan interaksi. Pada saat konseling konselor harus fokus pada klien, pada masalahnya dan pada apa yang dibutuhkan klien untuk mengatasi masalahnya. Jangan konselor berfikir mengenai kegiatan atau urusan lain diluar konseling.

Dokter Utami Roesli (69 tahun) menyampaikan bahwa konselor harus fokus pada klien selama konseling dan menghindari gangguan, "fokus pada klien jangan sampe keganggu sama bunyi handphone atau terburu-buru karena ada janji lain. Idealnya konseling itu 1,5 jam lebih dari itu ga efektif, minimal 30 menit, kurang dari itu juga gak efektif."

Mempertajam

Seringkali manusia mempertajam, satu atau dua aspek dari pesan yang disoroti, ditekankan dan mungkin juga dibumbui. Seringkali konsep yang kita pertajam adalah hal tertentu yang kebetulan menonjol dibandingkan yang lain.

\section{Asimilasi}

Asimilasi adalah kecenderungan untuk merekonstruksi pesan sedemikian hingga sesuai dengan sikap, prasangka, kebutuhan dan nilai pribadi seseorang.

Faktor kawan atau lawan

Faktor kawan atau lawan seringkali membuat seseorang mendistorsi pesan karena sikapnya terhadap orang lain. Karena itu konselor sebisa mungkin menjadi kawan bagi klien, sehingga klien akan lebih mudah menerima pesan positif yang disampaikan konselor

Mendengar yang diharapkan

Bila seseorang mendengarkan, seringkali dia terhanyut dalam pesan pembicara. Tetapi, ternyata orang tersebut tidak mendengar apa yang sebenarnya dikatakan dan sebaliknya mendengar apa yang dia harapkan.

Canriyana (29 tahun) mengatakan, "Kebanyakan mereka (klien) ingin ketemu konselor karena ingin ngobrol, curhat ingin didengerin, ingin diyakinkan kalau yang mereka lakukan tuh benar."

Teknik komunikasi lain adalah teknik bertanya. Konselor harus mengetahui bagaimana dan kapan memberikan pertanyaan dan pernyataan pada klien. Yaitu, dengan melihat dan memperhatikan kondisi klien, misalnya sewaktu klien kelihatan ingin berbicara tapi ragu, atau saat klien sudah menyimpang dari inti permasalahan. Tugas konselor adalah mencari tahu apa permasalahn yang dihadapi klien karena itu konselor harus terampil dalam membuka percakapan dan memancing klien untuk terbuka. Rasa keingintahuan konselor terhadap masalah yang dihadapi klien dilakukan dengan membuat pertanyaan-pertanyaan yang bersifat terbuka, yang membuat klien menjawabnya dengan senang hati. Oleh karena itu, konselor mengajukan pertanyaan dengan penuh perhatian dan kehangatan, disertai dengan tekanan suara yang bersahabat. Dengan perhatian dan kehangatan itu klien merasa diterima dan merasa semua masalahnya bisa diselesaikan. Tujuan konselor bertanya adalah untuk membantu klien mennyatakan isi hati dan perasaannya, membuka percakapan untuk memungkinkan munculnya pernyataan dan informasi baru, menolong klien untuk memulai berbicara, membantu klien untuk 
mengungkapkan dirinya, membantu klien untuk memberi contoh perilaku spesifik yang terjadi padanya.

Teknik komunkasi lain yang tidak kalah penting adalah teknik empati. Henry Backrack (1976), dalam DeVito (1997:260), mendefinisikan empati sebagai kemampuan untuk mengetahui apa yang sedang dialami orang lain pada suatu saat tertentu, dari sudut pandang orang lain itu, melalui kacamata orang lain itu.

Empati yang akurat menurut C.B Truax (1961)dalamDeVito(1997:260)melibatkanbaik kepekaan terhadap perasaan yang ada maupun fasilitas verbal untuk mengkomuniksaikan pengertian ini.

Langkah pertama dalam menyampaikan empati adalah menahan godaan untuk mengevaluasi, menilai, menafsirkan dan mengkritik. Bukan karena reaksi ini "salah", melainkan karena reaksi-reaksi seperti ini seringkali menghambat pemahaman. Fokusnya adalah pemahaman. Kedua, makin dalam seseorang mengenal orang lain -keinginan, pengalaman, kemampuannyua, ketakutannnya dan sebagainya -makin mampu orang tersebut melihat apa yang dilihat orang itu dan merasakan seperti apa yang dirasakannya. Ketiga, cobalah merasakan apa yang sedang dirasakan orang lain dari sudut pandangnya. Mainkanlah peran orang lain dalam pikiran sendiri. Hal ini dapat membantu seseorang untuk melihat dunia lebih dekat dengan apa yang dilihat orang itu.

Seseorang dapat mengkomunikasikan empati baik secara verbal maupun nonverbal. Secara nonverbal, empati dapat dikomunikasikan dengan memperlihatkan (1) keterlibatan aktif dengan orang itu melalui ekspresi wajah dan gerak -gerik sesuai; (2) konsentrasi terpusat pada kontak mata, postur tubuh yang penuh perhatian; dan (3) sentuhan atau belaian yang sepantasnya.

Jerry Authier dan Kay Gustafson (1982), dikutip DeVito (1997:261), menyarankan beberapa metode yang berguna untuk mengkomunikasikan empati secara verbal.

Merefleksi-balik kepada pembicara perasaan yang menurut komunikator sedang dialaminya. Ini membantu dalam memeriksa ketepatan persepsi konselor dan juga menunjukkan bahwa konselor berusaha memahami klien. - Membuat pernyataan tentative dan bukan mengajukan pertanyaan.Contohnya saat klien bercerita bahwa ia merasa penyebab kegagalannya menyusui adalah karena mertuanya tidak pro ASI dan ia tinggal bersama dengan mertuanya. Konselor sebaiknya jangan bertanya "Apa Mba marah pada mertua Mba?" tetapi, "Saya merasa kalau mba marah pada mertuanya"

- Pertanyakan pesan yang berbaur, pesan yang komponen verbal dan nonverbalnya saling bertentangan. Contohnya konselor berkata, "Mba bilang kalau mba bersyukur ada mertu yang mau bantu mengurusi bayi mba, tapi kok mba kelihatannya agak kecewa." Dengan mengajukan pertanyaan ini membantu menciptakan komunikasi ynag lebih terbuka dan jujur.

- Lakukan pengungkapan diri yang berkaitan dengan peristiwa dan perasaan klien untuk mengkomunikasikan pengrtian dan pemahaman terhadap apa yang sedang dialami klien. Misalnya konselor mengatakan, "Saya ngerti banget perasaan mba saat ini."

Teknik komunikasi terapeutik yang dilakukan konselor laktasi selanjutnya adalah menghindari kata menghakimi. Ilmu laktasi, breastfeeding dan konseling memang bisa dipelajari semua orang tapi tidak semua orang dapat menjadi konselor kompeten. Konselor yang kompeten adalah konselor yang telah berpengalaman dan mengerjakan konseling berulang-ulang. Salah satu kendala dalam komunikasi konseling adalah konselor terburu-buru melakukan penilain atau memberi tanggapan dengan kata-kata yang menilai, padahal menurut beberapa konselor judging word atau kata-kata penilaian harus dihindari. Hal ini karena menyusui itu tidak ada standarnya dan tidak ada salahnya.

Kata-kata yang memberi penilaian positif seperti bagus, benar,baik, tepat atau kata-kata seperti buruk, salah, cukup, jahat termasuk dalam kata judging words atau kata yang berarti menilai. Sebenarnya tidak ada yang salah dengan kata-kata itu tapi penggunaan kata-kata itu dalam konseling kadang membuat kebingungan pada klien. Misalnya saat konselor bertanya "Apakah bayi ibu menyusu dengan baik?" sekilas tidak ada yang salah dengan pertanyaan ini. Tapi pertanyaan seperti ini menunjukan ada standar untuk menyusui dan bayi klien mungkin 
tidak mencapai standar. Karena mungkin ada perbedaan persepsi antara klien dan konselor tentang maksud "menyusu baik".

Dalam konseling terkadang konselor perlu menggunakan kata menilai seperti "bagus" untuk membangun percaya diri klien. Tetapi jika konselor menggunakan kata-kata "menghakimi" mengenai kegiatan menyusui, terutama saat mengajukan pertanyaan, konselor bisa membuat klien merasa dirinya salah atau ada yang salah dengan bayinya.

Dalam konseling laktasi klien yang datang rata-rata memiliki masalah yang hampir sama yaitu ASI sedikit atau putting lecet, tapi sebenarnya masalahnya bukan itu. Bisa jadi karena ibu stress, kelelahan, ada masalah keluarga, kurang dukungan, kurang informasi, kurang percaya diri, dan masih banyak lagi. Saat konseling kllien yang datang sering kali berbicara panjang lebar dan memberikan pernyataan-pernyataan yang tidak relevan dengan masalahnya, atau mengungkapkan pendapatnya yang salah. Bila ini terjadi dan konselor mencoba membantah dan menyalahkan klien atas pernyataannya, maka yang terjadi adalah klien mengadakan pertahanan diri dan menghambat jalannya konseling itu sendiri. Karena klien dalam konseling ini tidak merasa diterima atau klien merasa konselor tidak mengerti masalah yang dihadapinya.

Yang harus dilakukan konselor adalah menerima apa yang klien sampaikan. Keberlangsungan konseling sangat ditentukan dari penerimaan dan pengertian dari diri konselor. Dengan penerimaan ini hubungan antara konselor dengan klien menjadi harmonis. Menerima bukan mengiyakan atau menyalahkan, hanya menerima. Teknik ini juga digunakan untuk menunjukan rasa minat dan pemahaman terhadap hal-hal yang dikemukakan klien. Jika klien telah menerima konselor untuk membantu masalah yangn dihadapinya, maka konselor dapat dengan mudah memberikan informasi dan saran.

Memuji adalah salah satu teknik komunikasi terapeutik konselor laktasi yang berbeda dengan teknik konseling lainnya. Memuji adalah perbuatan sepele yang memberikan banyak makna. Mereka yang hebat dan luar biasa sukses, biasanya sangat pandai memuji orang lain. Memuji sering dilakukan pada pembicara, politikus, pengusaha, atau orang yang berkecimpung dalam oraganisasi. Memuji bisa dikatakan sebagai sebuah seni yang perlu dipelajari tetapi tidak pernah diajarkan. Umumnya keterampilan memuji ini dipelajari secara natural, tapi bagi konselor, teknik memuji ini diajarkan dan dilatih karena berpengaruh pada keberhasilan konselor dalam memberi dukungan dan motivasi pada klien.

Memuji mempunyai dua elemen penting yang harus diperhatikan. Pertama adalah cara memuji yang benar. Maksudnya adalah pujian yang diberikan adalah benar, tidak mengarang dan mengada-ada. Kedua, memuji dengan tulus. Jadi ada kata benar dan tulus dalam pujian yang diberikan. Dengan memiliki keterampilan memuji dengan baik dan benar, maka klien akan senang bersahabat dengan konselor. Dari situ akan lebih mudah bagi klien untuk menerima informasi dan saran dari konselor. Memuji adalah sesuatu yang murah, mudah dan berguna bagi keberhasilan konselor.

Memuji perbuatan baik klien memiliki keuntungan sebagai berikut:

Membangun percaya diri klien

Mendorong klien terus melanjutkan perilaku baiknya

Membuat klien lebih mudah menerima saran berikutnya

Menyampaikan informasi adalah teknik keperawatan yang penting, karena dengan keterampilan ini perawat bisa berbagi informasi atau mengajarkan hal baru kepada pasien/klien, mengenai fakta seputar kesehatan. Umumnya klien datang kaerna kurang informasi, atau ia salah dalam menerima informasi dari media lain hingga ia mengalami kesalahan dalam menafsirkan informasi tersebut dalam tindakannya. Oleh karena itu sebaiknya konselor berusaha meluruskan informasi yang salah dan memberikan penjelasan kepada klien informasi yang benar Memberi informasi berbeda dengan memberi saran atau nasihat.

Informasi yang diberikan konselor pada klien adalah informasi yang relevan, maksudnya adalah informasi yang berguna untuk klien pada saat itu juga. Ada beberapa hal yang dilakukan konselor saat memberi klien informasi, diantaranya:

Sampaikan hal-hal yang dapat klien 
lakukan hari itu juga, bukan dalam beberapa minggu kedepan

Mencoba memberi klien hanya satu atau dua informasi pada saat itu, terutama bila klien dalam keadaan lelah, dan sudah menerima banyak saran

Memberi informasi dengan cara yang positif, agar tak terdengar seperti kritikan, atau membuat klien berfikir bahwa klien telah melakukan hal yang salah. Hal ini penting bila konselor ingin mengoreksi pendapat yang keliru.

Menunggu pemberian informasi sampai konselor berhasil membangun percaya diri klien, dengan menerima apa yang klien katakana, dan memuji apa yang telah klien lakukan dengan baik. Konselor tidak perlu terburu-buru memberikan informasi baru atau mengoreksi pendapat klien yang keliru.

Pemberian saran dalam konseling hendaknya dihindari, tetapi dapat diberikan jika memang sangat diperlukan atau ada permintaan dari klien sendiri. Memberikan saran dapat disalahgunakan klien, yaitu jika klien berusaha menghindar dari tanggung jawab pribadinya jika ia gagal mengatasi masalahnya dan akan dillimpahkan kepada konselor yang telah menasehatinya. Oleh karena itu konselor perlu mengetahui teknik yang benar saat memberi saran. Saran diberikan untuk membantu klien membuat keputusan bagi pemecahan masalah, bukan menyelesaikan masalah klien.

Dalam memberikan saran ini bisa dengan cara langsung, persuasive dan alternative. Saran secara langsung ini diberikan konselor karena ketidak tahuan klien terhadap apa yang akan dikerjakan, maka konselor dapat memberikan saran secara langsung. Sarang yang diberikan kepada klien secara persuasive, yaitu memberikan kesempatan klien untuk mengerti apa yang akan dikerjakan dan dirasakan, Persuasif ini diberikan karena klien mengemukakan alas an-alasan yang logis dari rencara yang akan dilakukan. Yang terakhir memberikan saran dengan menunjukan kepada klien beberapa kelebihan dan kelemahan apa yang klien akan lakukan. Konselor dan klien membahas kelemahan dan kelebihan atau faktor-faktor pendukung dan faktor-faktor penghambat serta pilihan diatas sehingga klien mengetahui kelebihan dan kelemahan masingmasing pilihan tersebut.

Penelitian komunikasi terapeutik konselor laktasi dengan klien relaktasi ini telah menunjukan bahwa kemampuan komunikasi tidak hanya dipelajari oleh ahli komunikasi atau mereka yang bergerak dimedia massa. Kemampuan komunikasi juga harus diliki oleh tenaga kesehatan khususnya konselor laktasi. Karena hubungan antara konselor dan klien adalah hubungan komunikasi antar pribadi yang bertujuan untuk kesehatan. Tenaga kesehatan yang menerapkan teknik-teknik komunikasi dalam interaksinya bersama pasien, lebih disukai oleh pasien atau klien. Sehingga pesan berupa informasi atau saran yang disampaikannya akan lebih mudah diterima oleh pasien atau klien. Perbedaan antara komunikasi konseling dengan bentuk komunikasi kesehatan lain terletak pada usaha konselor dengan keterampilan komunikasinya berusaha untuk melibatkan klien secara penuh dalam proses konseling. Komunikasi yang dilakkukan konselor pada klien bukan untuk mengatakan apa yang sebaiknya dilakukan oleh klien, tetapi meningkatkan rasa percaya diri klien sehingga klien sendiri yang akan memutuskan apa yang terbaik baginya.

\section{SIMPULAN}

Penelitian ini berangkat dari ditemukannya hubungan yang terapeutik antara konselor laktasi dengan klien relaktasi. Hubungan terapeutik ini ditandai dengan adanya sebuah ikatan antara konselor dengan klien, klien mau mendengarkan konselor, klien mempercayai konselor, kedekatan hubungan antara konselor dengan klien. Terjalinnya hubungan terapeutik selama konseling laktasi menimbulkan rasa ingin tahu peneliti tentang komunikasi dalam hubungan terapeutik tersebut dan faktor-faktor yang menentukan keberhasilan komunikasi dalam hubungan terapeutik tersebut.

Berdasarkan hasil observasi dan interview informan, peneliti menyimpulkan membagi komunikasi hubungan terapeutik dalam tiga tahapan, yaitu tahap membina hubungan baik, tahap pengumpulan informasi, dan yang terakhir tahap pemecahan masalah. Ketiga tahap ini berlangsung tanpa batasan yang jelas namun tiap tahapnya saling terkait satu sama lain. Bila tahap pertama tidak dilaksanakan dengan baik, maka akan sulit melaksanakan tahap selanjutnya.

Selama proses komunikasi terapeutik antara 
konselor laktasi dan klien relaktasi berlangsung, ada teknik-teknik komunikasi yang digunakan agar proses konseling berjalan efektif. Sepuluh teknik komunikasi terapeutik yang digunakan konselor laktasi dalam menghadapi klien relaktasi adalah: menggunakan komunikasi nonverbal yaitu kontak mata, parabahasa, sikap tubuh, komunikasi ruang, komunikasi sentuhan; teknik mendengarkan; teknik bertanya; penggunaan respons sederhana; menunjukkan empati; menghindari kata-kata menghakimi; menerima pendapat yang salah; mengenali dan memuji; pemberian informasi; dan yang terakhir pemberian saran.

Komunikasi terapeutik diperlukan selama proses konseling relaktasi karena sebagian besar kegiatan konseling adalah kegiatan komunikasi antarpribadi yang bertujuan untuk proses penyembuhan. Selama konseling berlangsung konselor menggunakan teknik-teknik komunikasi terapeutik untuk bisa membantu klien mengatasi kendalanya dalam menyusui. Berdasarkan hasil wawancara dan observasi di lapangan, kompetensi utama yang harus dimiliki konselor laktasi adalah kompetensi komunikasi.

\section{DAFTAR PUSTAKA}

Cresswell, John W. 1998. Qualitative Inquiry and Research Design. California: SAGE Publications

Devito, J. A. (1997). Komunikasi antarmanusia. Terjemahan Agus Maulana. Jakarta: Professional Books

Keliat, B. A. (1996). Hubungan terapeutik perawat-klien. Jakarta: EGC

Liliweri, A. (2007). Komunikasi kesehatan. Jogjakarta: Pustaka Pelajar

Rakhmat, J. (2005). Psikologi komunikasi. Bandung: Remaja Rosdakarya

Riset Kesehatan Dasar (Riskesdas) (2010)

Stuart, Gail Wiscarz dan Sandra J. Sundeen. 1991. Principles and Practice of Psychiatric Nursing. USA: Mosby

Hasil wawancara Kamis, 29 April 2014. Dengan dr. Utami Roesli SpA.IBCLC

Hasil wawancara Rabu, 9 April 2014. Dengan Rahmah Housniati S.Sos, MKM, IBCLC 